DOI $10.4467 / 2543733 X S S B .17 .002 .7248$

DANUTA QUIRINI-POPŁAWSKA

Uniwersytet Jagielloński

\title{
NIEZNANA MATRICULAZIONE UNIVERSITÀ LEGISTA POLONA UNIWERSYTETU PADEWSKIEGO Z LAT 1591-1598
}

Słowa kluczowe: Uniwersytet Padewski, Metryka polska, lata 1591-1598, polscy studenci, ich znaki szczególne

Badania nad studiami Polaków na Uniwersytecie Padewskim w późnym średniowieczu i renesansie mają wprawdzie długą chronologię, ale prowadzone były sporadycznie i wyrywkowo. Niewątpliwie wpływ na taki stan badań miało, i ma, znaczne rozproszenie materiału źródłowego, a także brak Album Studiosorum Universitatis Pataviensis. Podkreślić zatem wypadnie, że gros autorów, którzy interesowali się pobytem i studiami Polaków w Padwie, przybliżało głównie losy i kariery pojedynczych padewskich scholarów, względnie grupy należącej do jednego zawodu (medycy, poeci, prawnicy, pisarze), powiązanych miejscem pochodzenia (Kraków, Lwów) lub późniejszym miejscem pracy (Akademia Krakowska). Wielu autorów omawiało przekrojowo kontakty polsko-włoskie, poruszając równocześnie w swych pracach znaczenie podróży Polaków na studia do Italii w średniowieczu i w renesansie.

Nieocenione zasługi na polu poznania roli, jaką odegrały studia Polaków we Włoszech, położył Henryk Barycz. On to już w 1971 r. opublikował Metrykę nacji polskiej w Uniwersytecie Padewskim (1592-1745)․ Nacja germańska wcześniej, bo od 1546 r., zadbała o prowadzenie metryki uniwersytetu prawniczego $<$ Matricula nationis germanicae iuristarum in Gymnasio Patavino, t. I (1546-1605), a cura di Elisabetta Dalla Francesca Hellman, Roma-Padova 2007>, ale wydała ją drukiem dopiero w 2007 r. Druga jej część, obejmująca wpisy na studia medyczne, filozoficzne oraz teologiczne, rozpoczynająca się w 1553 r.: Matricula nationis germanicae artistarum in Gymnasio Patavino (1553-1721), a cura di Lucia Rossetti, Padova 1986, została opublikowana nieco wcześ-

${ }^{1}$ Archiwum nacji polskiej w Uniwersytecie Padewskim, t. I, Metryka nacji polskiej w Uniwersytecie Padewskim (1592-1745), do druku przyg. Henryk Barycz, indeks osób Karolina Targosz, Wrocław-Warszawa-Kraków-Gdańsk 1971. 
niej, bo w 1986 r. Z powyższych danych wynika, że Polacy najwcześniej zainteresowali się publikacją metryki zawierającej spis osób pochodzących z terenów Rzeczypospolitej, które podjęły studia na Uniwersytecie Padewskim.

Jak już podkreślono, Uniwersytet Padewski nie posiada księgi immatrykulacyjnej studentów, stąd istnieje podstawowa trudność w obliczeniu liczby polskich scholarów studiujących na tej uczelni. W miarę pełnymi danymi dysponujemy dopiero od $1592 \mathrm{r}$.; znajdują się one w Metryce polskiej opublikowanej przez Henryka Barycza. Jednak z najnowszych badań wynika, że do Metryki polskiej nie wpisywali się wszyscy mieszkańcy z obszarów Korony i Litwy, także ci, którzy z Padwy wywozili dyplom doktorski. Część nie dokonywała wpisów w ogóle, nazwiska zaś niektórych, głównie pochodzących z Gdańska, Elbląga, Torunia, Malborka, a nawet Poznania, znajdujemy w dokumentach Metryki nacji niemieckiej.

W latach 1592-1600 wpisało się do Metryki polskiej 318 osób pochodzących z terenów Korony i Litwy. Nie był to jednak ostateczny i jedyny zapis Metryki Natio Polona ${ }^{2}$. Już w 1892 roku Blasio Brugi i Aloysio Andrich opublikowali w Rotulus et matricula, nieznany także Henrykowi Baryczowi, spis polskich studentów w Padwie pt. Natio Polona. Zawiera on łącznie 62 wpisy studentów; zamieszczone zostały w nim również dwa nazwiska cudzoziemców (Nicolas Popl Liber Baro de Lobconicz oraz Nicolas Vracensis) ${ }^{3}$. Z kolei 56 studentów dokonało wpisu w 1592 r., zaś 6 w 1593 r. Większość nazwisk scholarów znajduje się w opublikowanej przez Henryka Barycza Metryce polskiej, natomiast pięciu scholarów (Johannes Cichowicz, Cornelius Corbus, Stanislaus Gankomski de Garokov (czy Karnkowski?), Johannes Picumski i Christophorus Widoczki de Budzisław) nie było dotąd znanych. Trzech polskich studentów, a to: Jerzy Zbaraski, Krzysztof Karśnicki i Jan Mniszek, dokonało dwukrotnie wpisów do omawianego spisu studentów nacji polskiej. Także nie jest pewne, czy podane nazwiska: Johannes Chelowig i Nicolas Chelowig należy utożsamiać z Janem i Mikołajem Chlebowiczami, zastanawiać bowiem może fakt, że w tym spisie studentów wpisali się osobno. Dodatkowo przy 12 studentach widnieją zapisane znaki szczególne twarzy oraz rą $\mathrm{k}^{4}$. Dla porównania załączam, opublikowany w Rotulus et matricula w wersji oryginalnej, spis nazwisk polskich studentów w Padwie:

1. d. Johannes Picumski

2. d.Valentinus Fontana

3. d.Cornelius Corbus

4. d. Nicolas Popl Liber Baro a Lobconicz

5. d.Sigismundus Peremschi

6. d.Matheus Pomerzanchil

2 Archivio Antico dell'Università di Padova, vol. 487, Acta inclytae Nationis Polonae, s. 39-54.

3 Ponadto Nicolaus Popl liber baro a Lobcoviz występuje w Padwie 24 września 1592 r. jako świadek przy nadaniu stopnia doktora pobojga praw Janowi Giselerusowi z Gdańska , zaś Palatinides Nicolaus Vracensis również jako świadek przy nadania stopnia doktora obojga praw Jerzemu Scipiadesowi Sowińskiemu 13 lutego 1593 r. Acta graduum academicorum Gymnasii Patavini ab anno 1566 ad annum 1600 (1591-1600), t. IV/4, a cura di E. Martellozzo Forin, Roma-Padova 2008, nr 2733, 2768.

${ }^{4}$ Rotulus et matricula D.D. Juristarum et artistarum Gymnasii Patavini A. MDXCII-III, curantibus Blasio Brugi e Aloysio Andrich, Patavii MDCCCXCII, Natio Polona, s. 10-11. 
7. d. Marcus Oliensnicki con nationis Poloniae

8. d. Martinus Sziskowski canonicus cracoviensis

9. d. Henricus Firhi palatinides cracoviensis

10. d. palatinides Jo. Cichowicz ${ }^{5}$

11. d. Nicolas Vracensis

12. d. Jacobus comes de Ostroróg

13. d. Albertus Gaiewschsi

14. d. Gasparus Slegel polonus

15. d. Johannes Chelowig Polonus

16. d. Nicolas Chelowig Polonus

17. D. Christophorus z Baraschi Palatinides Bracła: duos aureos die 3 augusti 1592

18. D. Jacobus Rozuadouski nob. Polonus cum cicatrice in naso, die dicta (3 aug.)

19. d. Stanislaus Rosrazewski unum scutum

20. d. Henricus Rosrazewski unum scutum

21. d. Jan Hlebowicz na Dąbrownie Stolnik Wiel-o XL dal ung. 2 (mortuus), cum cicatrice in Manu dextra sub Juncturam pollicis die dicta 30 Aug.

22. D. Nicolai Hlebowicz na Dąbrownie Woiewodzicz Trocki dat ung. 2 (postea castellanus Vilnensis, mortuus tempore Electionis Serenissimi Vladioxti Regis Pol.) cum signis nigris in fatie 30 aug. 1592

23. d. Jacobus Broniewski lib. 5 (cum cicatrice in police dextro) 30 aug.-ti

24. d. Mikolai Potoczki lib. 10 Po.

25. d. Jan Gądeczki lib. 1

26. d. Hieronimus Reczaiski unun scutum

27. d. Georgius Pipanus dedit unum scutum

28. d. Hieronimus Rapp dedit unum scutum (cum cicatrice in collo) die 30 sept. 1592

29. d. Jo-s Wesile Polonus cum veruca in fatie in sinistra parte 21 octo. 1592

30. d. Andreas comes a Thęczyn capitaneus Strzeiensis dedit duos ungaricos

31. d. Christopherus Sassino (Sassina) Carzsziczki gnesnensis cracov. can.: dedit unum ungaricum

32. d. Christophorus Falenczki unum scutum (cum cicatrice in manu sinistra digito annicularis 22 octob. 1592

33. d. Stanislaus Gankomski de Garokov Polonus cum cicatrice in maxilla sinistra 16 novembris 1592

34. d. Joannes Ozdrziwolski unum scutum

35. d. Jerzy z Baraskie woiewodzicz Bracezławski, starosta Piński trzy scuty (Sokalchy?) iam castellanus Cracoviensis mortuus forli Apoplexia $1629(?)^{6}$

36. d. Stanislaus Kisewski Abbas Lublin: Sigismundi Tertio Regis Poloniae secretarius dedit unum ungaricum

\footnotetext{
${ }^{5}$ Może można go zidentyfikować z Johannes Joannis Czechovicius dioc. Leopoliensis, wpisanym do Albumu studentów Uniwersytetu Krakowskiego w 1589 r.: Album Studiosorum Universitatis Cracoviensis, t. III, ed. A. Chmiel, Cracoviae 1904, s. 162.

${ }^{6}$ Kasztelanem krakowskim do 5 kwietnia 1592 r. był Seweryn Boner z Balic, od 1593 r. Janusz Ostrogski, wojewoda wołyński, następnie w 1620 r. urząd ten objął Jerzy Zbaraski starosta piński i sokalski, zmarły 30 lipca 1631 r. K. P ieradzka, Boner Seweryn z Balic, Polski słownik biograficzny, t. II, Kraków 1936, s. 301-302; T. Chynczews ka-Henne 1, Ostrogski Janusz ksiązę, Polski słownik biograficzny, t. XXIV, Wrocław-Warszawa-Kraków-Gdańsk 1979, s. 481-486; Urzędnicy województwa krakowskiego XVI-XVIII wieku. Spisy, red. A. Gąsiorowski, Kórnik 1990, s. 61. Rotulus et Matricula, s. 10. Być może wpis: Sokalchy jest ciągiem dalszym informacji o Jerzym Zbaraskim i oznacza, że był on starostą sokalskim.
} 
37. d. Andreas de Bnin Opalenski Prepositus Plocensis dedit unum ungaricum Jam Episcopus Posnaniensis (mortuus)

38. Christophorus Wiesolowski a Wiesolow dedit libras duodecim (cum veruca in mento) 15 Januarij 1593

39. Ill-mus ac m-cus D. Georgius dux de Sbaras Polonus 17 januarii $1593^{7}$

40. d. Nicolaus Griczki dedit unum scutum

41. d. Stanislaus Gembiczki Abbas. Ploc.: unum ungaricum

42. d. Gabriel comes in Thenczyn dedit duos ungaricos (cum parva veruca in dextera parte faciem 3 februarii 1593

43. d. Georgius Tysckowicz de Loborsk Palatinides Bresten. dedit ung. Duos

44. d. Christophorus Sassino (Sasina) Carnsniczki gneznen. Cracovi.: Wladisl. Canon.: nomie Ill Andreae Gabrieli Comitum a Theczyn contulit ad hoc pium opus et auxit aerarium communitatis scutis Decem

45. d. Thomas Tretherus canon: Warm.: dedit lib. 7

46. d. Andreas Debinski unum dedit ungaricum

47. d. Andreas Sapiua cast.: Mienski dedit quatuor ungaricos

48. d. Hieronimus Godziąthowski lib. 7 (cum cicatrice in indice sinistro die 14 februarij 1593

49. d. Mathias Sobkowicz custos Scarbimirn. obtulit lib. septem

50. d. Joannes Chocziszewski dedit lib. septem

51. d. Stanislaus Dembienski unum scutum

52. Fr. Gregorius Ostrowski Prepositus Tarnovien.: ex Maiori Polonia ordinis Cistercien. in Wogrowiecz professus ab Abbatibus Poloniae sui ordinis ad Sedem Apostolicam Nuncius unum ungaricum contulit

53. d. Mathyas Hurkovicius Przemislin., quatuor lib.

54. d. Joannes et

55. d. Stanislaus Mniszkowie dederunt duodecym libra

56. d. Martinus Okregliczki lib. Sex

57. d. Hieronimus Czyżowski de Czyżów dedit unum ungaricalem florenum

58. d. Martinus Gereon Liczko de Orlowicze dedit ung. unum

59. d. Christophorus Widoczki de Budzisław dedit libra septem

60. Ill-mus D-ns D-ns Nicolaus Christophorus Radziwit Dux de Olica et Nieswiesz comes in Szydlowiecz Sacrosanti Sepulchri Herosolimitani Miles Palatinus Trocensis cum esset Patavy cum Ill-a coniuge sua causa recuperandae valetudinis dedit ad hoc prium opus et nationis Polonicae Lithwaniaeque honorem ung. Decem

61. d. Abramus Felix Cracoviensis cum cicatrice in fronte Polonus. Die prima Junij 1593

62. Illustris. Et Mag-cus Dominus Johannes Muisszek Palatinides Sandomiridu polonus die 2 Junij $1593^{8}$.

Natomiast w księdze opatrzonej numerem 30 (z dawną sygnaturą 677 zbioru Minato) w Archivio Antico dell'Università di Padova na stronach od 43 r. do 46 v, pod tytułem Matriculazione Università Legista Polona, znajdujemy wpisy osób pochodzących z terenów Korony i Litwy z okresu od 30 września 1591 r. (czyli rozpoczynające się rok wcześniej niż Metryka opublikowana przez Henryka Barycza) do 8 września 1598 r., przystępujących w tym czasie na Uniwersytecie Padewskim do studiów prawniczych. Spis ten został sporządzony jedną ręką, notariusza uniwersyteckiego Antonio Villaniego, na co wskazuje

\footnotetext{
7 Jerzy Zborowski został wpisany do tej metryki dwukrotnie.

8 Ibidem, s. 11.
} 
ten sam charakter pisma, ale tylko do 10 listopada 1597 r. Cztery ostatnie nazwiska zostały wpisane przez innego notariusza, co było konsekwencją śmierci poprzedniego?.

Z wstępnych ustaleń dotyczących studiów Polaków na Uniwersytecie Padewskim w późnym średniowieczu i renesansie wynika, że studia prawnicze podejmowali w większości przedstawiciele szlachty, tylko niektórzy spośród nich studiowali teologię. Medycynę i filozofię studiowali głównie mieszczanie, pochodzący z większych polskich, ruskich i litewskich miast.

Nowo odnaleziona lista studentów pochodzących z terenów Korony i Litwy liczy 83 nazwiska, plus 6 nazwisk scholarów z dodatkiem Austriacus lub Germanus. Nazwiska studentów wpisanych do tej części Matriculazione w dużej mierze pokrywają się z listą opublikowaną przez Henryka Barycza. Jednak wśród 83 osób znajduje się 20 nieznanych dotąd nazwisk studentów, których nie umieszczono w opublikowanej Metryce, a także nie ma ich w przebadanych materiałach archiwalnych w Archivio Antico w Padwie. Tym samym potwierdza się wysnute już powyżej przypuszczenie, że do Metryki Polskiej wpisywała się tylko część studentów - ale jaka? Pod uwagę trzeba wziąć także fakt, że omawiana Matriculazione z lat 1591-1598 rejestruje tylko dane dotyczące polskich studentów z uniwersytetu prawniczego.

Dodać również należy, że we wspomnianej księdze opatrzonej numerem 30 na stronach $10 \mathrm{v}$ - do 30 verso znajduje się Matriculazione Università Legista Natione Germana z 11 nazwiskami studentów pochodzących z Gdańska i Torunia. Jest tam także jeszcze kilka nazwisk studentów z dopiskiem „Prutenus, Borussus”, ale ich identyfikacja wymaga dokładnej weryfikacji.

Ponieważ tekst nowo odnalezionej Matriculazione Università Legista Polona, z księgi nr 30, nie był jeszcze publikowany, przytaczamy jego oryginalną treść:

\section{f. $43 \mathrm{r}$}

1. Magnificus Dominus Joannes Mieleczkÿ a Mielius Polonus cum cicatrice in Manu dextera 30 Septembris 1591

2. Illustrissimus Dominus Dominus Henricus Firlei de Dombroviza Polonus cum Fissura in indice sinistro 17 Octobris 1591

3. Dominus Felix Kobrztinski Prutenus Polonus cum porro in Manu sinistra 17 Octobris 1591

4. Dominus Sygismundus Porembsky Polonus cum cicatrice in digito indicis sinistri 26 Novembris 1591

5. Dominus Petrus Opÿeczig Polonus cum cicatrice in Manu sinistra 4 Decembris 1591

6. Illustrissimuss et Reverendissimus Dominus Arnolphus Uchansky comes de Sluzewo divina providentia Abbas Suleroviensis Polonus 14 Decembris 1591

7. Dominus Adrianus Konwicz Polonus 24 Januarii 1592

8. Nobilis Dominus Christophorus Chelmskÿ Polonus cum verruca et cicatrice in fronte 17 Februarii 1592

9. Dominus Marcus Olesnicius de Olesniki cum cicatrice in jndice dextero 13 Februarii 1592

10. Illustrissimus Dominus Sbigneus de Brzezie Lanczkorunski polonus cum cicatrice in digito fidio sinistro 19 Martii 1592

${ }^{9}$ Archivio Antico dell’Università di Padova, vol. 30, s. 7. Antonio Villani (de Villanis) pracował na Uniwersytecie Padewskiem jako notariusz od 1591 r. do śmierci, tj. do 6 lutego 1598 r. (zaznaczono to w księdze vise Sue diem 6 februarÿ 1598). 
11. Dominus Stanislaus Ostrorog nobilis Polonus 8 Aprilis 1592

12. Dominus Adamus Bratosserockÿ nobilis Polonus cum signo in sinistra frontis parte die 9 Aprilis 1592

f. $43 \mathrm{v}$

13. Dominus Lucas Kosmonskÿ Posnaniensis Polonus cum signo in police dextero 23 Aprilis 1592

14. Illustrissimu Dominus Joannes Skumin Palatinides Novogrodensis hospitaneus bratislaviensis Lithvanus (Lituvanus) Polonus cum verucca in aure sinistra 12 Maÿ 1592

15. Nobilis Dominus Stanislaus Skorulsky Lituvanus polonus cum cicutrice in Manu dextera die dicta

16. Nobilis Dominus Albertus Bichovviecz Lituvanus cum Verruca in maxilla sinistra die dicta

17. Nobilis Dominus Daniel Polubiensky Lituvanus cum verruca in mentum die dicta

18. Nobilis Dominus Lucas Mosalskÿ Lituvanus cum cicatrice in fronte die dicta

19. Nobilis Dominus Georgius Mosalskÿ Lituvanus die dicta

20. Dominus Albertus Gaiowsky nobilis polonus cum cicatrice in facie 27 Junii 1592

21. Dominus Martinus Siscovski canonicus Carcovie polonus cum signo rubeo in Manu dextera 6 Julij 1592

22. Dominus Stanislaus Scavvevski (Scarzewski) polonus die dicta

23. Nobilis Dominus Adrianus Gostomskÿ de Liczenicze Polonus cum cicatrice penes oculum sinistrum 17 Julij 1592

24. Nobilis Dominus Joannes Rosskowskÿ de Górka polonus cum cicatrice in medio digito sinistro die dicta

25. Nobilis Dominus Joannes Piotrowskÿ de Maiori Piotrowycze Polonus Die dicta

s. $44 \mathrm{r}$

26. Nobilis Dominus Wladislaus Przeimskÿ de Golina polonus cum verruca in maxilla sinistra die 17 Julii 1592

27. Nobilis Dominus Joannes Sslawossowsky polonus cum cicatrice in jndice sinistro die dicta

28. Nobilis Dominus Andreas Kechliczkÿ polonus cum macula penes pollicem sinistram 17 Julii 1592

29. Ls/i4 Illustrissimus Dominus Christophorus Sbaraski de Sbaras Palatinides Braclaviensis die 3 Augusti 1592

30. Dominus Jacobus Rozvadovski nobilis polonus cum cicatrice in naso die dicta

31. Magnificus Dominus Nicolaus Hlebowicz in Dambrowna cum signis nigris in facie $30 \mathrm{Au}-$ gusti 1592

32. Magnificus Dominus Joannes Hlebowicz in Dambrowna cum cicatrice in Manu dextra ad iuncturam pollicis die dicta

33. Nobilis Dominus Jacobus Bromeroski Polonus cum cicatrice in police destro 30 Augusti (1592)

34. Dominus Hieronimus Raff polonus cum cicatrice in collo die 30 Septembris 1592

35. Dominus Joannes Wesik Polonus cum veruca in facie in sinistra parte 21 Octobris 1592

36. Dominus Christophorus Falecki Polonus cum cicatrice in $\mathrm{ma}(\mathrm{nu})$ sinistra digito auriculari 22 Octobris 1592

s. $44 \mathrm{v}$

37. Dominus Stanislaus Gzarnkowski de Gzarnkow Polonus cum circatrice in maxilla sinistra 16 Novembris 1592

38. Dominus Christophorus Wiesietoreski polonus cum veruca in mento 15 Januarÿ 1593 
39. Illustrissimus et Magnificus Dominus Georgius dux de Sbaras pollonus 17 Januarÿ 1593

40. Illustrissimus Dominus Gabriel comes in Tecin pollonus cum parva lesura in dextera parte faciei 3 Februarii 1593

41. Dominus Hieronimus Gorgi Bialikowski Polonus cum circatrice in indice sinistro die $24 \mathrm{Fe}-$ bruarii 1593

42. Dominus Abramus Felix Cracoviensis cum cicatrice in fronte Polonus die prima Junÿ 1593

43. Illustrissimus et Magnificus Dominus Joannes Mnissek palatinides sandomiridum Polonus die 2 Junÿ 1593

44. Dominus Jacobus comes ab Ostrowo Consiliarius Nationis Polonae die 21 Septembris 1593

45. Dominus Hieronimus Reczaiskÿ Polonus cum cicatrice in medio digito manus dextere die dicta

46. Dominus Thomas Stempowsky cum cicatrice in lewa parte faciej die 26 Octobris 1593

47. Dominus Stanislaus Sulovischy nobilis polonus cum veruca in parte dextera Nasi die 21 Marcÿ 1594

48. Dominus Sebastianus Posnaniensis nobilis polonus habens cicatricem ad mediam juncturam digiti indicis dextri die dicta

49. Dominus Nicolaus Gizycki polonus cum cicatrice in police sinistro die dicta ${ }^{10}$

50. Dominus Daniel Fich Dantiscano cum cicatrice in pollice manu sinistri die 7 Aprilis 1594

51. Rubertus Ruffinuus (Ruppinus ?) cum cicatrice in faciem die dicta

s. $45 \mathrm{r}$

52. Dominus Stanislaus Czieklenskÿ de Czeklin Pollonus cum cicatrice in sinistro digito die 18 Junÿ 1594

53. Dominus Hieronimus Dembinski Pollonus cum cicatrice in police sinistro 29 Junÿ 1594

54. Dominus Georgius Niemoictoskÿ Pollonus cum cicatrice in maxilla sinistra die dicta

55. Dominus Symon Bar pollonus cum cicatrice in supericilio sinistro die dicta

56. Dominus Stanislaus Zorawinskj Polonus cum veruca in utraque gena 26 decembris 1595

57. Dominus Gaspar Niewiarowski Pollonus cum cicatrice in manu sinistra penes policem die 30 Julii 1595

58. Dominus Georgius comes ab Ostrorog Pollonus (die) 20 Decembris 1595

59. Dominus Joannes Serny Eques Polonus cum cicatrice in Manu dextera 16 Februarii 1596

60. Dominus Felix Stupecky (Slupecsky?) polonus cum verruca sub inferiori labro 27 Martÿ 1596

61. Dominus Adamus Svyniarsky nobilis polonus cum una lente ad aurem dexteram die 31 Martÿ 1596

62. Dominus Joannes de Lezenice Gostomschi polonus cum parva cicatrice in labro 17 Aprilis 1596

63. Dominus Lucas Comorschi polonus cum cicatrice in minimo digito sinistro die dicta

64. Dominus Joannes Trepka Polonus cum cicatrice super manu sinistra Die 26 Maÿ 1596

S. $45 \mathrm{v}$

65. Dominus Nicolaus Walensky (Walevsky?) polonus cum lente nigra in sinistra parte nasi 28 Maÿ 1596

66. Dominus Alexander Zborowschy polonus cum cicatrice ad pollicem manus dextre $20 \mathrm{Au}-$ gusti 1596

67. Dominus Adamus Sopocko nobilis Polonus cum cicatrice super oculo sinistro 1596

${ }^{10}$ Być może jest nim Nicolaus Martini Gizicki dioc. Gnesnensis, wpisany do Albumu studentów Akademii Krakowskiej w 1590 r.: Album studiosorum Universitatis Cracoviensis, t. III, s. 164. 
68. Dominus Adamus Klisovistz polonus cum cicatrice super verticem capitis 31 Augusti 1596

69. Dominus Joannes Malinski polonus cum cicatrice super indice sinistro (die) 2 Septembris 1596

Dominus Joannes Henricus ab Haldenstein Germanus 12 Octobris 1596

Dominus Lazarus Henkelius junior Germanus 14 Octobris 1596

Dominus Philippus Jacobus Fuert Austriacus Germanus die 5 Octobris 1596

Dominus Hieronimus Fuert austriacus die dicta

Dominus Johannes Renardus ab Auw die dicta

Dominus Joannes Georgius a Klingenburg Rhazingprum Germanus ${ }^{11}$ die dicta

70. Dominus Georgius Wisniewieckÿ Polonus cum verucca in dextera mala die. die 15 Octobris 1596

71. Dominus Joannes Karwickÿ pollonus cum parva cicatrice sub mento a parte sinistra die dicta

72. Dominus Joannes Didinskÿ polonus cum cicatrice in facie in parte dextera die 19 Aprillis 1597

73. Dominus Alexander Simhowic Polonus cum verruca in dextera parte colli 13 Maÿ 1597

s. $46 \mathrm{r}$

74. Dominus Stanislaus Droiowski polonus cum verugine in facie a parte dextera ad aurem 23 Junÿ 1597

75. Dominus Martinus Boianecki Pollonus cum cicatrice in medio pollicis sinistri 30 Junÿ 1597

76. Dominus Stanislaus Didinsky Pollonus cum cicatrice in manu dextera 20 Julÿ 1597

77. Dominus Nicolaus Gisieschi Pollonus cum cicatrice in manu sinistra die

78. Dominus Joannes Bletnickÿ (Bletnictkÿ) polonus cum cicatrice in police dextera 1 Novembris 1597

79. Dominus Joannes Karmkowsky polonus cum signo in digito auriculari dextro 10 Novembris 1597

80. Dominus Nicolaus a Kuczkon Koczkorosky cum veruca in faciem Polonus die 10 Februarÿ 1598

81. Dominus Lucas Sierakowskÿ Polonus cum, cicatrice in summitate nasi die 17 Martii 1598

82. Dominus Nicolaus Lanckÿ Polonus cum parva cicatrice in fronte die 2 mensis Junii 1598

83. Dominus Joannes Czarnkowsky Polonus cum porro in gutture die 20 mensis Julii $1598^{12}$

Wśród nazwisk nowych scholarów, dotąd nieidentyfikowanych ze studiami na Uniwersytecie Padewskim, pojawia się nazwisko prymasa Polski Jana Wężyka herbu Wąż, syna Hieronima, wpisanego do metryki Uniwersytetu Krakowskiego w 1591 r. jako Johannes Jeronymi Wezik de Wola Wezikowa, dioc. gnesn. W rok potem przybył do Padwy i jego nazwisko znajdujemy w Matriculazione Università Legista Polona pod datą 21 października 1592 r. W Padwie pozostał co najmniej przez rok, gdyż jeszcze 2 października 1593 r. był świadkiem przy obronie doktorskiej Walentego Fontany oraz poświadczał jego

${ }^{11}$ Nazwiska pięciu Niemców widnieją w Metryce niemieckiej: Matricula nationis germanicae iuristarum in Gymnasio Patavino, t. I 1546-1605, a cura di Elisabetta Dalla Francesca Hellmann, Roma-Padova 2007, nr 5009 (Lazarus Henkel (Henkelius) iunior a Donnerstmarkh), nr 5010 (Philippus Jacobus Fuert Austriacus), nr 5011 (Hieronimus Fuert Austriacus), nr 5012 (Joannes Renardus ab Auco), nr 5013 (Joannes Georgius a Khienburg i $n$ Khatingsprun).

${ }^{12} \mathrm{~W}$ tym miejscu pragnę złożyć serdeczne podziękowania p. mgr Annie Sobańskiej, kierowniczce Działu Rękopisów Biblioteki Jagiellońskiej za weryfikację tekstu tego rękopisu, bowiem odczytanie niektórych wyrazów utrudniał zły stan jego zachowania. 
wyznanie wiary katolickiej ${ }^{13}$. Nie wiadomo, jak długo pozostał w mieście św. Antoniego i kiedy przeniósł się do Rzymu (jego wyjazd trzeba więc przesunąć z 1591 na 1593 r.), gdzie uzyskał około 1604 r. podwójny doktorat - z teologii i prawa. W Polsce został opatem mogilskim w 1613 r., biskupem przemyskim (od 1620), następnie poznańskim (od 1624), aby w 1627 r. osiąść na stolicy gnieźnieńskiej (do śmierci w 1638 r.) $)^{14}$.

Dnia 14 kwietnia 1596 r. wpisał się do nowej metryki Jan Gostomski h. Nałęcz (1576-1623) z Leżenic, starosta wałecki (1588), warecki (1590), grójecki, gębiński, strzelecki, dworzanin królewski, poseł w 1599 r. na dwór praski, poseł na sejm w 1611 r., wojewoda inowrocławski, wojewoda brzesko-kujawski w 1620 r. i w tymże roku wojewoda kaliski, protektor jezuitów ${ }^{15}$.

Jakub Ostrowski herbu Nałęcz z ziemi chełmskiej (zm. 1638 r.), kanonik krakowski, pisarz polemiczny oraz kaznodzieja, do nowej Metryki w Padwie wpisał się 21 września 1593 r. Wedle Haliny Kowalskiej uzyskał stopień doktora świętej teologii we Włoszech, w 1613 r. kanonik włocławski, pleban niepołomicki, w 1607 kanonik krakowski oraz główny penitencjarz katedry krakowskiej. Był autorem utworów polemicznych, jak choćby Dialog albo rozmowa katolika z ewangelikiem (1604), W obronie kazania Piotra Skargi (1608). Kazania, a dał się poznać jako znakomity kaznodzieja, głosił także u św. Barbary. Dochody z beneficjów przeznaczał na pobożne cele. Został pochowany w krakowskiej katedrze ${ }^{16}$.

W nowej metryce wpisali się też 12 maja 1592 r.: Daniel Połubiński z książęcego rodu, h. Jastrzębiec, syn Andrzeja ${ }^{17}$, Mikołaj Giżycki, syn Marcina, stolnika gostyńskiego, dworzanin królewski, dziedzic Osiemborowa, podkomorzy czerski, poseł na sejm i deputat do Rady Wojennej 1620 r., kasztelan czerski 1622 r., zmarły w 1637 r. wśród scholarów Uniwersytetu Padewskiego znalazł się 21 marca 1594 r. ${ }^{18}$

Do interesujących, a zupełnie nieznanych byłych studentów padewskich należy Korneliusz Korb, syn Jerzego z Warszawy. W Padwie spotykamy go po raz pierwszy 2 czerwca 1589 r. w charakterze świadka przy obronie pracy doktorskiej z zakresu medycyny Jakuba Grodzickiego z Poznania ${ }^{19}$.Następnie przeniósł się do Bolonii, gdzie poznawszy słynnego medyka i botanika Ulissesa Aldrovandiego, zwiedził jego muzeum różności przyrodniczych. Na wspomnianym uniwersytecie doktoryzował się w zakresie medycyny 20 sierpnia $1590 \mathrm{r}^{20} \mathrm{Nie}$ zakończył na tym swych studiów, ponieważ ponownie pojawił się w Padwie prawdopodobnie już w 1592 r., zaś 3 lipca 1593 r. wystąpił w charakterze

13 Acta graduum academicorum, t. IV/4, nr 2856.

${ }^{14}$ L. Łę tow s k i, Katalog biskupów, prałatów i kanoników krakowskich, t. IV, Kraków 1853, s. 213-221;

H. B a ry c z, Polacy na studiach w Rzymie w epoce Odrodzenia (1440-1600), Kraków 1938, s. 220.

15 W. D w or za c ze k, Gostomski Jan z Leźenic, Polski słownik biograficzny, t. VIII, Wrocław-KrakówWarszawa 1959-1960, s. 366-367.

${ }^{16}$ H. K ow a ls k a, Ostrowski Jakub h. Nałęcz, Polski słownik biograficzny, t. XXIV, Wrocław-WarszawaKraków-Gdańsk 1979, ss. 551-552; S. Uruski, Rodzina, t. XIII, Warszawa 1916, s. 101.

17 S. Urus k i, Rodzina, t. XIV, Warszawa 1917, s. 209.

18 S. Uru s ki, Rodzina, t. IV, Warszawa 1904, s. 169.

19 Acta graduum academicorum Gymnasii Patavini ab anno 1566 ad annum 1600 (1576- 1590), t. IV/ 3, a cura di E. Martellozzo Forin, Roma-Padova 2008, nr 2830.

${ }^{20}$ F. G i e d r o y ć, Źródla biograficzno-bibliograficzne do dziejów medycyny w dawnej Polsce, Warszawa 1911, s. 140; D. Qu ir in i-P o pła w s k a, I visitatori Polacchi del museo di oggetti naturali di Ulisse Aldrovandi, w: Commentationes historicae, red. D. Quirini-Popławska, Warszawa-Kraków 1988, s. 155. 
świadka przy obronie pracy doktorskiej z zakresu medycyny Antoniego Schneebergera ${ }^{21}$. Wkrótce powrócił do Polski i osiadł w rodzinnej Warszawie, gdzie dał się poznać jako ceniony lekarz ${ }^{22}$.

Identyfikacja pozostałych polskich studentów znajdujących się w nieznanej dotąd Metryce zajmie zapewne jeszcze wiele czasu. Niemniej najistotniejszym elementem tej nowo odnalezionej części Metryki jest fakt, że gros scholarów podawało obok danych personalnych, a więc nazwiska, imienia, zawsze przynależność państwową (Polonus, Lithuanus, czasem Lituanus Polonus, Prutenus Polonus), nobilis dominus, magnificus dominus, illustrissimus dominus, reverendissimus dominus, czasem piastowane stanowisko oraz nazwę miasta, $\mathrm{z}$ którego pochodzili, ale równocześnie rzecz zupełnie nieznaną w środowisku uniwersyteckim - a to cechy charakterystyczne ich fizjonomii, twarzy, rąk oraz szyi i rzucające się w oczy znamiona.

I tak dowiadujemy się m.in., że Jan Mielecki miał bliznę na prawej ręce; Henryk Firlej - bliznę na palcu wskazującym u lewej ręki; Krzysztof Chełmski - brodawkę i szramę na czole; Jan Skupin - brodawkę na lewym uchu; Daniel Połubiński - brodawkę na podbródku; Mikołaj Hlebowicz - czarne plamy na twarzy; Marcin Szyszkowski - czarny znak na prawej dłoni; Adrian Gostomski - bliznę koło lewego oka; Jakub Rozwadowski bliznę na nosie; Krzysztof Fałęcki - bliznę na palcu serdecznym lewej ręki; Daniel Fisch z Gdańska - bliznę na wierzchniej lewej dłoni; Feliks Słupecki - brodawkę na dolnej wardze; Adam Klimowicz - bliznę na wierzchołku głowy; Jan Karwicki miał małą szramę po lewej stronie podbródka; Łukasz Sierakowski - bliznę na wierzchołku nosa.

Co jednak ciekawe, spośród 83 osób znajdujących się na nowej liście Metryki prawników jedenastu studentów nie miało znaków szczególnych lub ich nie podało. Byli wśród nich synowie najznakomitszych polskich rodów, m.in.: Jan Mniszek, Jakub Ostrowski, dwaj Ostrorogowie - Jerzy i Stanisław, książęta Zbarascy - Jerzy i Krzysztof, opat sulejowski Arnold Uchański. Nie zauważono też żadnych znamion u zapisanych w tej Metryce 6 Austriaków i Niemców. A drugiej strony zachodzi pytanie, dlaczego właśnie ich nazwiska umieszczono w Metryce polskich prawników? Na żadnym europejskim uniwersytecie - jak mi wiadomo - nie spotkano się z podobną Metryką studencką. Miałby to być znak rozpoznawczy, pomagający w identyfikacji poszczególnych osób. Niemniej znaki szczególne u wielu wspomnianych studentów nie różniły się znacznie pomiędzy sobą. Zatem na odpowiedź, komu i czemu ich podanie miało właściwie służyć, trzeba będzie jeszcze poczekać.

A oto nowa lista polskich studentów, ułożona alfabetycznie, z lat 1591-1598, których nazwiska widnieją w obu omówionych nowych metrykach Uniwersytetu Padewskiego, ale nie znajdujemy ich w Metryce polskiej opublikowanej przez Henryka Barycza:

1. Dominus Abramus Felix Cracoviensis cum cicatrice in fronte Polonus die prima Junÿ 1593

2. Nobilis Dominus Albertus Bichovviecz Lithuanus cum verruca in maxilla ministra 12 Maÿ 1592

3. Dominus Joannes Bletnickÿ polonus cum cicatrice in Police dextera 1 Novembris 1597

4. D. Jo. palatinides Cichowicz ( 1592)

5. D. Cornelius Corbus (1592)

${ }^{21}$ Acta graduum academicorum Gymnasii Patavini, t. IV/3, nr 2830.

${ }^{22}$ F. G i e d r o y ć, Źródła biograficzno-bibliograficzne, s. 366. 
6. Dominus Daniel Fich Dantiscanus cum cicatrice in pollice manu sinistri 4 Aprilis 1594

7. D. Stanislaus Gankomski de Garokov Polonus cum cicatrice in maxilla ministra 16 novembris 1592

8. Dominus Nicolas Gisieschi Polonus cum cicatrice in manu ministra 20 Julÿ 1597

9. Dominus Nicolas Giżycki polonus cum cicatrice in Police sinistro 21 Marcÿ 1594

10. Dominus Johannes de Lezenice Gostomschi polonus cum parva cicatrice in labro 17 Aprilis 1596

11. Nobilis Dominus Andreas Kechliczky polonus cum macula penes pollicem sinistram 17 Julii 1592

12. Dominus Adamus Klisovistz polonus cum cicatrice super in verticem capitis 31 Augusti 1596

13. Dominus Lucas Comorschi polonus cum cicatrice in minomo digito sinistro 17 Aprilis 1596

14. Dominus Adrianus Konwicz Polonus 24 Januarii 1592

15. Dominus Lucas Kosmonskÿ Posnaniensis Polonus cum signo in police dextero 23 Aprilis 1592

16. Dominus Nicolaus Lancky Polonus cum parva cicatrice in fronte die 2 Junii 1598

17. Dominus Petrus Opÿeczig Polonus cum cicatrice in manu ministra 4 Decembris 1591

18. Dominus Jacobus comes ab Ostrowo consiliarius Nationis Polonie die 21 Settembris 1593

19. D. Johannes Picumski (1592)

20. Nobilis Dominus Daniel Polubiensky Lituvanus in verruca in mentum 12 Maÿ 1592

21. Dominus Jacobus Rozvadovski nobilis polonus cum cicatrice in naso 3 Augusti 1592.

22. Dominus Stanislaus Scavvevski polonus 6 Julii 1592.

23. Nobilis Dominus Stanislaus Skorulsky Lituvanus polonus cum cicatrice in manu dextera 12 Maÿ 1592

24. Dominus Joannes Wesik Polonus cum veruca in facie in ministra parte 21 Octobris 1592

25. D. Christophorus Widoczki de Budzisław dedit libra septem (1592).

Dokonując szczegółowej analizy wszystkich wpisów padewskich scholarów do obu metryk z lat 1591-1600, trzeba podkreślić następujące ich cechy charakterystyczne:

1. Obie Metryki nie rejestrują wszystkich studiujących na Uniwersytecie Padewskim mieszkańców Korony i Litwy. Z dotychczasowych badań wynika, że około 50 studentów (z okresu 1591-1600), których obecność w Padwie jest potwierdzona źródłowo, nie zapisało się do żadnej z tych Metryk. W nowej Metryce prawników zanotowano tylko jedno nazwisko studenta pochodzącego z Gdańska, w Metryce opublikowanej przez Henryka Barycza nie występują w ogóle studenci z Gdańska, Malborka, Torunia i Elbląga. Ich nazwiska znajdujemy w Metryce prawników i medyków nacji germańskiej. W omawianym okresie potwierdzone są źródłowo studia 16 studentów z Gdańska (Kasper Fidler uzyskał doktorat z medycyny w 1592 r., a Jan Gisler doktorat obojga praw w 1592 r.), oraz 2 z Elbląga, zaś na identyfikację innych z dodatkiem Borussus, Prutenus trzeba jeszcze poczekać.

2. Przeglądając nazwiska, a co więcej, śledząc życiorysy studentów z obu Metryk nacji polskiej (łącznie około 340 osób), dochodzimy do zaskakującego wniosku. Gros studentów z lat 1591-1600, około 80\%, to przedstawiciele rodów możnowładczych i szlacheckich. To oni studiowali z reguły prawo, choć tylko nieliczni uzyskiwali stopień doktora obojga praw (konkretnie trzy osoby, jeden doktorat $z$ teologii). Natomiast poznawali także inne europejskie uniwersytety, zatrzymując się w nich na jakiś czas, podejmowali także wycieczki turystyczno-edukacyjne do różnych miejscowości we Włoszech i Europie Zachodniej. Zdobywali w ten sposób tak potrzebną im ogładę światową, uczyli się języków, przyglądali się różnym 
formom zarządzania i administracji, zwanej przez Włochów sprezzatura. To dawni studenci i absolwenci Uniwersytetu Padewskiego objęli później najważniejsze godności i stanowiska świeckie i kościelne w ówczesnej Polsce.

3. Można też się zastanawiać nad spadkiem zainteresowania $w$ omawianych latach 1592-1600 studiami zagranicznymi ze strony polskich synów mieszczan. Tłumaczyć to wypadnie pogarszającą się sytuacją gospodarczą polskich miast, w tym Krakowa. Wiązać również tę sytuację trzeba z upadkiem roli i znaczenia Akademii Krakowskiej. Na dzień dzisiejszy przyjąć można - biorąc pod uwagę podawane przez studentów miejsce pochodzenia oraz ich dalsze losy, że w Padwie w latach 1590-1600 studiowało około 50 studentów pochodzenia mieszczańskiego (zanotowanych w Metrykach polskich) oraz 18 mieszczan z Gdańska i Elbląga - w Metryce nacji germańskiej. Mając na uwadze 340 studentów wpisanych do wszystkich Metryk, można przyjąć, że studiujący mieszczanie stanowili około $15 \%$ lub co najwyżej $18 \%$.

4. Przyjrzyjmy się, jak wygląda ta statystyka uwzględniająca miejsca pochodzenia badanych padewczyków pochodzenia mieszczańskiego:

Elbląg - 2 studentów; Gdańsk - 16; Kazimierz - 1; Korzeńsk - 1; Kościan - 1; Kraków - 12; Krosno - 1; Lublin - 2; Lwów - 5; Łowicz - 1; Pilzno - 2; Poznań - 9; Przasnysz - 1; Przemyśl - 2; Przeworsk - 1; Radymno - 1; Sandomierz - 2; Warszawa - 4; Wieliczka - 1; Wielbutów -1. Uderza znaczna liczba studentów pochodzących z Gdańska, którzy noszą nazwiska niemieckie, a ich wpisy znajdujemy w Metryce nacji germańskiej.

W omawianym okresie 23 studentów pochodzących z terenów Korony i Litwy uzyskało stopień doktora filozofii i medycyny (gros spośród mieszczan), 3 doktorat $\mathrm{z}$ zakresu obojga praw oraz 1 osoba $\mathrm{z}$ teologii. Biorąc pod uwagę powyższe obliczenia, można zaryzykować tezę, że pomimo spadku zainteresowania studiami zagranicznymi przez synów mieszczańskich, pod koniec XVI wieku nie osłabły chęć i zapał do uwieńczenia studiów na Uniwersytecie Padewskim stopniem doktora (w XVI wieku stopień doktora uzyskało 144 Polaków).

5. Na koniec trzeba podkreślić, że kwerendą, oprócz różnych rękopisów znajdujących się w Archivio Antico, zostały w pewnej części objęte Atti dei notai del Distritto di Padova w Archivio di Stato, zawierające około 5 tys. nazwisk notariuszy (z lat 1303-1868 - jest 11,724 notariuszy i ich akt). Aby jednak uzyskać pożądane rezultaty i posunąć naprzód dotychczasową wiedzę na temat obecności i studiów mieszkańców dawnej Rzeczypospolitej na Uniwersytecie Padewskim, badania winien podjąć zespół badaczy, nie tylko przygotowanych do nich merytorycznie, ale entuzjastów, zafascynowanych kwerendami źródłowymi.

\section{Bibliografia}

Źródła rękopiśmienne:

Archivio Antico dell’Università degli Studi di Padova, vol. 30, vol. 487.

Żródła drukowane:

Acta graduum academicorum Gymnasii Patavini ab anno 1566 ad annum 1600 (1576-1590), t. IV/3, a cura di E. Martellozzo Forin, Roma-Padova 2008 
Acta graduum academicorum Gymnasii Patavini ab anno 1566 ad annum 1660 (1591-1600), t. IV/4, a cura di E. Martellozzo Forin, Roma-Padova 2008

Album studiosorum Universitatis Cracoviensis, t. III, ed. A. Chmiel, Cracoviae 1904

Archiwum nacji polskiej w Uniwersytecie Padewskim, t. I, Metryka nacji polskiej w Uniwersytecie Padewskim (1592-1745), do druku przyg. Henryk Barycz, indeks osób Karolina Targosz, Wrocław-Warszawa-Kraków-Gdańsk 1971

Matricula nationis germanicae iuristarum Gymnasio Patavino, t. I (1546-1605), a cura di E. Dalla Francesca Hellman, Roma-Padova 2007

Rotulus et matricula D.D. iuristarum et artistarum Gymnasii Patavini A. MDXCII-III, curatibus Blasio Brugi e Aloysio Andrich, Patavii 1892

Bibliografia

Barycz Henryk, Polacy na studiach w Rzymie w epoce Odrodzenia (1440-1600), Kraków 1938

Chynczewska-Hennel Teresa, Ostrogski Janusz, książę, Polski słownik biograficzny, t. XXIV, Wrocław-Warszawa-Kraków-Gdańsk 1979

Dworzaczek Włodzimierz, Gostomski Jan z Leżenic, Polski słownik biograficzny, t. VIII, WrocławKraków-Warszawa 1959-1960

Giedroyć Franciszek, Źródła biograficzno-bibliograficzne do dziejów medycyny w dawnej Polsce, Warszawa 1911

Kowalska Halina, Ostrowski Jakub h. Nałęcz, Polski słownik biograficzny, t. XXIV, Wrocław-Warszawa-Kraków-Gdańsk 1979

Łętowski Ludwik, Katalog biskupów, prałatów i kanoników krakowskich, t. IV, Kraków 1853

Pieradzka Krystyna, Boner Seweryn z Balic, Polski słownik biograficzny, t. II, Kraków 1936

Quirini-Popławska Danuta, I visitatori Polacchiii del museo di oggetti naturali di Ulisses Aldrovandi, [w:] Commentationes historicae, red. D. Quirini-Popławska, Warszawa-Kraków 1988

Urzędnicy województwa krakowskiego XVI-XVIII wieku. Spisy, red. A. Gąsiorowski, Kórnik 1990.

Danuta Quirini-Popławska

\section{The Unknown Matriculazione Università Legista Polona of the University of Padua from the Years 1591-1598}

\section{Summary}

The article is devoted to the part of Matriculazione Università Legista Polona from the years 1591-1598, found in the book No. 30 in the Archivio Antico dell'Università degli Studi di Padova and published for the first time. It is one of the results of the in-depth analysis of the archive, which has been carried out by the author for five years now. The public register consists of 83 entries of people from areas of the former Reczpospolita and, additionally, 6 names of Austrians and Germans. The set of names is supplemented by the list, published by Blasio Brugi and Aloysio Andrich in 1892 in Rotulus et matricula. The hitherto unknown list, entitled Natio Polona, was produced in the years 1592-1593 and contains 62 names. the fact that the majority of scholars coming from the area of the former Rzeczpospolita made entries in this public register of lawyers, providing their distinguishing marks, including birthmarks, scars, gashes and warts located on their faces, arms and necks is interesting and puzzling. Thus far, this kind of information has not been seen in the analysed public registers of European universities. In addition, following the comparison of the names of persons entered in the Register of the Polish nation ("Metryka nacji polskiej"), published by Henryk 
Barycz, the author of the article identified 25 names of Polish scholars, not listed elsewhere. Hence, the important conclusion is that, in the years $1592-1600$, not all Polish scholars from the University of Padua were registered in the official Register of the Polish nation, and so, the number of Polish students at this university may have been much higher than previously estimated.

Key words: University of Padua - The Polish Register - the years 1591-1598 - Polish students - their distinguishing marks. 